\title{
STUDI PENDAHULUAN KONSTRUKSI PETA PAUTAN GENETIK DAN IDENTIFIKASI QUANTITATIVE TRAIT LOCI YANG TERPAUT DENGAN PERTUMBUHAN AWAL TANAMAN KARET
}

\author{
Prelimenary Study of Genetic Linked Map Construction and Identification of \\ Quantitative Trait Loci Linked to Early Growth of Rubber Plant \\ Fetrina Oktavia \\ Pusat Penelitian Karet, Jln Raya Palembang - Pangkalan Balai KM 29, Sembawa \\ Banyuasin 30593 Sumatera Selatan \\ *Email : fetrina_oktavia@yahoo.com
}

Diterima : 12 Juli 2020 / Disetujui : 12 Oktober 2020

\begin{abstract}
Hevea brasiliensis is one of the main species producing of natural rubber. Efforts to develop a new superior rubber clones that have high latex yielding and good agronomic characters need to be carried out in a continuously. One limiting factor for this effort is a long selection time around 25-35 years. An alternative approach that can be used to overcome this problem is selection assisted by molecular markers. The research aimed to construct a genetic linkage map and identification of QTLs linked to early rubber plant growth. QTLs can be used as a molecular marker for early detection of growth of girth potential of rubber clones. The analysis was carried out on $201 \mathrm{~F} 1$ progeny obtained from crosses of $P B 260 \times$ SP 217 clones. Phenotyping of girth data was carried out on F1 plants aged 16-22 months that planted in five ha area. The genetic link maps of population were compiled by using 263 of selected SSR markers. The observation showed that the growth of girth population on 22 months old ranged from 5.5 to $25.04 \mathrm{~cm}$ with an average of $14.66 \mathrm{~cm}$. The average girth increasing of $F 1$ progenies per month ranges from $0.4-1 \mathrm{~cm}$. The coefficient variance showed that there is a high diversity growth of girth of population. Three of QTLs linked to early growth of girth rubber plant on 22 months after planting were succesfull identified on LG 14 with LOD 4.64, LG 13 LOD 3.5, and LG 1 LOD 3. QTL linked to increasing of girth from 16 to 22 months old was identified in LG 14 with LOD 4.1. The position of the loci of genes or DNA sequence that had effect to growth of girth was indicated by the TAs2185 marker where the marker give $11.7 \%$ of effect to growth of girth rubber plant.
\end{abstract}

To know the stability and the application of marker assisted selection for girth as a tool for selection, the existence of the QTLs needs to be analyzed periodically.

Keywords : genetic linkage map; Hevea brasiliensis; progeny; QTL; SSR

\begin{abstract}
Abstrak
Hevea brasiliensis merupakan salah satu spesies utama penghasil karet alam. Upaya pengembangan klon-klon karet unggul baru yang memiliki produksi lateks tinggi dan karakter agronomis yang baik perlu dilakukan secara berkelanjutan. Salah satu faktor pembatas upaya tersebut adalah lamanya waktu seleksi yang dibutuhkan yakni berkisar 25-35 tahun. Pendekatan alternatif yang dapat digunakan untuk mengatasi permasalahan tersebut adalah seleksi dengan bantuan marka molekuler. Penelitian ini bertujuan untuk menyusun peta pautan genetik dan identifikasi QTL yang terpaut dengan pertumbuhan awal tanaman karet. QTL dapat digunakan sebagai penanda molekuler untuk deteksi dini potensi pertumbuhan lilit batang klon karet. Analisis dilakukan pada 201 progeni F1 hasil persilangan klon PB 260 x SP 217. Fenotipe data pertumbuhan lilit batang dilakukan pada tanaman F1 umur 16-22 bulan yang ditanam pada areal seluas lima ha. Penyusunan peta pautan genetik populasi dilakukan menggunakan 263 marka SSR terseleksi. Pengamatan menunjukkan bahwa pertumbuhan lilit batang populasi umur 22 bulan berkisar 5,5 $-25,04 \mathrm{~cm}$ dengan rata-rata $14,66 \mathrm{~cm}$. Ratarata penambahan lilit batang progeni $\mathrm{F} 1$
\end{abstract}


setiap bulan berkisar 0,4-1 cm. Koefisien keragaman menunjukkan bahwa terdapat keragaman pertumbuhan lilit batang yang cukup tinggi pada populasi. Tiga QTL yang terpaut pertumbuhan awal lilit batang tanaman karet umur 22 bulan setelah tanam berhasil teridentifikasi pada LG 14 dengan LOD 4,64, LG 13 dengan LOD 3,5, dan LG 1 dengan LOD 3. Pada LG 14 dengan LOD 4,1 berhasil teridentifikasi QTL terpaut peningkatan lilit batang dari umur 16 sampai 22 bulan. Posisi lokus gen atau sekuen DNA yang memberikan pengaruh terhadap pertumbuhan lilit batang tersebut ditunjukkan oleh marka TAs2185 di mana gen tersebut memberikan pengaruh sebesar $11,7 \%$ terhadap pertumbuhan lilit batang tanaman karet. Keberadaan QTL tersebut perlu dianalisis secara berkala untuk mengetahui kestabilan sehingga dapat digunakan sebagai alat bantu seleksi untuk lilit batang.

Kata kunci: Hevea brasiliensis; peta pautan genetik; progeni; QTL; SSR

\section{PENDAHULUAN}

Tanaman karet (Hevea brasiliensis Muell Arg) merupakan spesies utama penghasil karet alam. Spesies yang termasuk ke dalam famili Euphorbiaceae tersebut berasal dari lembah Amazon dan tumbuh baik di daerah tropis. Hingga saat ini $92 \%$ produksi karet alam dunia disumbangkan oleh negara-negara penghasil karet alam di Asia Tenggara termasuk Indonesia.

Upaya peningkatan produktivitas perkebunan karet melalui penggunaan klonklon unggul baru perlu terus dilakukan. Program pemuliaan pengembangan klonklon baru secara umum masih dilakukan melalui pendekatan konvensional melalui hibridisasi dan berbagai tahapan seleksi yang membutuhkan waktu cukup lama berkisar 20 - 25 tahun. Hal ini menjadi tantangan dalam program pemuliaan tanaman karet, sehingga perkembangan kemajuan di bidang molekuler menjadi harapan untuk memperpendek masa seleksi dengan bantuan penanda molekuler (Marka Asissted Selection atau MAS). Seleksi dengan bantuan marka molekuler dapat dilakukan secara cepat dan akurat, di mana seleksi dapat dilakukan secara dini pada tahap awal pertumbuhan tanaman.

Pengembangan MAS berbasiskan Quantitative Trait Loci (QTL), yaitu lokus atau bagian dari genom yang menyandikan suatu karakter dari tanaman. Identifikasi keberadaan QTL yang terpaut erat dengan suatu karakter yang diinginkan dilakukan dengan melihat keterpautan antara karakter tersebut (fenotipe) dengan faktor marka genetik (genotipe). QTL akan teridentifikasi apabila ditemukan keterpautan yang erat antara kedua faktor tersebut. Nilai pautan antara kedua faktor tersebut ditentukan berdasarkan nilai LOD (logarithmic of odds) di mana semakin tinggi nilai LOD akan semakin kuat pautan antara karakter dengan marka genetik. Secara umum suatu marka genetik dapat dianggap signifikan terpaut dengan suatu karakter pada nilai LOD 3. Pengaruh QTL terhadap variasi karakter fenotipik dijelaskan berdasarkan nilai $\mathrm{R}^{2}$, di mana pengaruh QTL akan tergolong mayor pada saat nilai $\mathrm{R}^{2}$ diatas 0,1 dan minor pada saat nilai $R^{2}$ kurang dari 0,1 . Secara umum QTL mayor relatif stabil pada semua kondisi, sedangkan QTL minor sensitif terhadap pengaruh lingkungan sehingga seringkali keberadaannya tidak terdeteksi di semua tahap dan kondisi pertumbuhan tanaman (Collard et al., 2005; Semagn et al., 2006; Khan, 2015).

Secara umum analisis QTL dilakukan pada populasi F2 atau backcross. Pada tanaman tahunan seperti tanaman karet hal ini sulit untuk dilakukan karena siklus hidup tanaman yang panjang dan kemampuan menghasilkan biji yang rendah akibat adanya inbreeding depression (Lespinasse et al., 2000). Keterbatasan tersebut menyebabkan hanya turunan F1 yang dihasilkan dari persilangan tetua yang heterozigot yang biasanya mungkin disiapkan sebagai populasi pemetaan di mana kondisi ini dapat mengakibatkan terjadinya segregasi empat alel pada satu lokus. Data yang dihasilkan dapat dianalisis sebagai double pseudotestcross dan penyusunan peta genetik untuk masingmasing tetua dilakukan secara terpisah (Grattapaglia \& Sederoff, 1994).

Analisis QTL pada tanaman karet dilaporkan telah dikembangkan secara luas untuk berbagai karakter agronomis, seperti 
ketahanan terhadap penyakit gugur daun South American Leaf Blight (SALB) (Le Guen et al., 2003; Le-Guen et al., 2007; Le Guen et al., 2011 a; Le Guen et al., 2013) dan penyakit gugur daun Corynespora (Tranh et al., 2016; Oktavia et al., 2021), pertumbuhan tanaman (; Novalina, 2013; Souza et al., 2011; Souza et al., 2013; Conson et al., 2018), serta QTL yang terpaut dengan produksi lateks (Chanroj et al., 2017; Rosa et al., 2018; An et al., 2019). Pada analisis tersebut dilakukan penyusunan peta pautan genetik pada berbagai populasi $\mathrm{F} 1$ hasil persilangan klon tetua yang berbeda. Penelitian ini bertujuan untuk mengidentifikasi QTL yang terpaut dengan pertumbuhan tanaman karet menggunakan populasi $\mathrm{F} 1$ hasil persilangan PB 260 x SP 217.

\section{BAHAN DAN METODE}

\section{Waktu dan Tempat Penelitian}

Penelitian dilaksanakan di Kebun Percobaan dan Laboratorium Fisiologi Pusat Penelitian Karet, Sembawa, Banyuasin, Sumatera Selatan serta Laboratorium Bios, Cirad, Perancis dari tahun 2016-2018.

\section{Materi tanaman}

Analisis QTL dilakukan pada progeni F1 hasil persilangan klon PB 260 x SP 217 yang ditanam di lapangan pada areal seluas 5 ha. Penelitian menggunakan Rancangan Acak Kelompok yang terdiri dari 201 progeni F1 dan setiap progeni ditanam sebanyak 2 pohon dengan lima ulangan.

\section{Metode Penelitian}

Penelitian terdiri dari tiga tahapan, yaitu phenotyping yang terdiri dari beberapa tahapan yaitu pengamatan pertumbuhan lilit batang setiap bulan selama dua tahun serta analisis data pertumbuhan (phenotyping), penyusunan peta pautan genetik atau genetic linkage group (LG) menggunakan software joint map (genotyping), serta identifikasi keberadaan QTL yang merupakan penggabungan data phenotyping dan genotyping menggunakan software Map QTL.

\section{Evaluasi Pertumbuhan Tanaman F1 di Lapangan (Phenotyping)}

Evaluasi pertumbuhan dilakukan melalui pengukuran lilit batang semua genotipe F1 setiap bulan pada saat tanaman berumur 16 sampai 22 bulan. Pengukuran lilit batang dilakukan pada tahun kedua pertumbuhan di ketinggian $150 \mathrm{~cm}$ dari pertautan okulasi (dpo) menggunakan meteran.

\section{Analisis Molekuler dengan Penanda SSR (Genotyping)}

\section{Isolasi DNA}

Sampel daun karet muda dikoleksi dari masing-masing progeni $\mathrm{F} 1$ dan kedua klon tetua di kebun percobaan dan langsung digunakan untuk isolasi DNA total. DNA total sebagai template untuk analisis SSR diisolasi berdasarkan metode OrozcoCastillo et al. (1994) dengan beberapa modifikasi. Satu gram daun muda dari masing-masing aksesi digerus dengan penambahan 0,1 g PVP (polivenil pirolidon) dan nitrogen cair sampai dihasilkan serbuk daun yang halus. Selanjutnya serbuk dimasukkan ke dalam $5 \mathrm{ml}$ buffer ekstraksi yang telah dipanaskan dan diberi mercaptoethanol 1\%, di vortex serta dipanaskan selama 30 menit pada suhu 65 ${ }^{\circ} \mathrm{C}$.

Sampel kemudian didinginkan pada suhu kamar, ditambahkan dengan $5 \mathrm{ml}$ (24:1) chloroform:isoamilalkohol (CI) dan divortex. Sampel disentrifus selama 10 menit dengan kecepatan $11.000 \mathrm{rpm}$ pada suhu ruang. Cairan bagian atas dipipet ke tabung baru dan ditambahkan dengan isopropanol dingin sebanyak satu volume. Sampel dikocok secara perlahan sampai homogen dan selanjutnya disimpan pada suhu $4{ }^{\circ} \mathrm{C}$ selama 30 menit, dan disentrifus 10 menit dengan kecepatan $11.000 \mathrm{rpm}$. Selanjutnya pellet DNA diambil dan dikeringkan. DNA yang diperoleh dilarutkan dalam $1 \mathrm{ml}$ buffer TE (10 M Tris- $\mathrm{HCl} \mathrm{pH} 8,0$, 1 M EDTA), lalu ditambahkan $\mathrm{CH}_{3} \mathrm{COONa} 3$ M pH 5,2 sebanyak $1 / 1 \mathrm{~V}$ dan ethanol absolut sebanyak 2,5 $\mathrm{ml}$, selanjutnya dikocok sampai homogen dan disimpan pada suhu $-20{ }^{\circ} \mathrm{C}$ selama 20 menit. 
Selanjutnya campuran disentrifus 10 menit dengan kecepatan $12.000 \mathrm{rpm}$ pada suhu 4 ${ }^{\circ} \mathrm{C}$, dan pellet DNA yang diperoleh dicuci dengan ethanol $70 \%$ dan dikeringkan. Kemudian pellet dilarutkan dalam 1001 buffer TE dan disimpan pada suhu $-20{ }^{\circ} \mathrm{C}$. Kualitas dan kuantitas DNA diuji menggunakan elektroforesis agarose $1 \%$.

\section{Amplifikasi PCR}

Genotyping dilakukan dengan menggunakan 263 primer SSR terseleksi koleksi Laboratorium Bios, Cirad (Le Guen et al., 2011b). Reaksi PCR dilakukan dalam volume $25 \mu 1$ yang terdiri dari 1x PCR buffer, 0,2 mM dNTP mix, $2 \mathrm{mM} \mathrm{MgCl}_{2}$, 0,5 U Taq polymerase (Kapa Biosystem Inc. USA), 0,2 $\mu \mathrm{M}$ masing-masing primer, dan $5 \mathrm{ng}$ template DNA. Volume akhir diatur menjadi $25 \mu 1$ dengan menambahkan nuclease free water. Amplifikasi dilakukan menggunakan DNA thermal cycler (Thermal Cycler Applied Biosystem) dengan menggunakan program denaturasi awal pada $95^{\circ} \mathrm{C}$ selama 3 menit, diikuti denaturasi pada $95{ }^{\circ} \mathrm{C}$ selama 15 detik, annealing $53-56{ }^{\circ} \mathrm{C}$ selama 30 detik, extention $72^{\circ} \mathrm{C}$ selama 10 detik sebanyak 35 siklus, dan final extention pada $72{ }^{\circ} \mathrm{C}$ selama 10 menit.

Hasil PCR selanjutnya dikuantifikasi dan dilakukan pelabelan menggunakan fluoresent. Elektroforesis hasil amplifikasi PCR dengan primer SSR dilakukan secara sistem kapiler menggunakan alat Genetic Analyzer (Applied Biosystem). Hasil elektroforesis selanjutnya dianalisis menggunakan software GeneMapper version 4.0.

\section{Penyusunan Peta Pautan Genetik dan Identifikasi QTL}

Hasil genotyping 263 marka SSR digunakan untuk menyusun peta pautan genetik 201 progeni F1 menggunakan software Joint Map 4.1. Peta pautan genetik (linkage group) 201 progeni $\mathrm{F} 1$ hasil persilangan klon PB 260 dengan SP 217 disusun pada marker SSR yang bersegregasi dengan pola $1: 1: 1: 1,1: 2: 1,3: 1$, dan 1:1. Pola segregasi masing-masing progeni pada setiap lokus dilakukan dengan lima tipe sistem pengkodean seperti yang tercantum pada Tabel 1 .

Analisis QTL dilakukan menggunakan prosedur interval mapping (IM) seperti yang dijelaskan oleh Lander \& Botstein (1989) serta prosedur multiple QTL mapping (MQM) menggunakan cofactor marker dengan skor nilai LOD tertinggi pada analisis IM yang dilakukan sebelumnya (Jansen, 1993). Selanjutnya untuk melihat segregasi masing-masing lokus dilakukan test nonparametric Kruskal-Wallis (KW) (Ooijen, 2004). Keberadaan QTL dilakukan berdasarkan LOD di atas 3. QTL yang berada pada LOD di bawah 3 merupakan putative QTL yang tingkat signifikansinya masih rendah. Identifikasi keberadaan QTL yang terpaut pertumbuhan lilit batang dilakukan menggunakan software Map QTL.

Tabel 1. Sistem pengkodean pola segregasi populasi pemetaan hasil persilangan PB $260 \mathrm{x}$ SP 217 dengan marka SSR

Table 1. Coding system of segregation pattern of mapping population obtained crossing of $P B$ $260 \times$ SP 217 by using SSR marker

\begin{tabular}{ccccc}
\hline $\begin{array}{c}\text { No } \\
\text { No }\end{array}$ & $\begin{array}{c}\text { Kode } \\
\text { Code }\end{array}$ & $\begin{array}{c}\text { Posisi Lokus Heterozigot } \\
\text { Position of Heterizogous Locus }\end{array}$ & $\begin{array}{c}\text { Rasio } \\
\text { Ratio }\end{array}$ & $\begin{array}{c}\text { Jumlah Alel } \\
\text { Number of Allele }\end{array}$ \\
\hline 1 & ab x cd & Kedua tetua & $1: 1: 1: 1$ & 4 \\
2 & eg x eg & Kedua tetua & $1: 2: 1$ & 3 \\
3 & hk x hk & Kedua tetua & $1: 2: 1$ atau 3:1 & 3 \\
4 & lm x ll & Satu tetua & $1: 1$ & 2 \\
5 & nn x np & Satu tetua lain & $1: 1$ & 2 \\
\hline
\end{tabular}




\section{HASIL DAN PEMBAHASAN}

\section{Pertumbuhan Lilit Batang Tanaman F1 Hasil Persilangan PB $260 \times$ SP 217 (Phenotyping)}

Evaluasi pertumbuhan 201 genotipe F1 dan klon tetua dilakukan setiap bulan dari umur 16 sampai 22 bulan dengan cara pengukuran lilit batang pada ketinggian 150 $\mathrm{cm}$ dpo. Hasil pengukuran menunjukkan bahwa lilit batang tanaman F1 pada TBM umur 22 bulan berkisar 5,5-25,04 cm dengan rata-rata $14,66 \mathrm{~cm}$. Rata-rata penambahan lilit batang progeni F1 setiap bulan berkisar 0,4 $-1 \mathrm{~cm}$ setiap bulan. Berdasarkan koefisien keragaman $(18,83)$ terlihat bahwa terdapat keragaman pertumbuhan lilit batang yang cukup tinggi pada progeni $\mathrm{F} 1$ yang menunjukkan adanya segregasi karakter pertumbuhan lilit batang (Gambar 1).

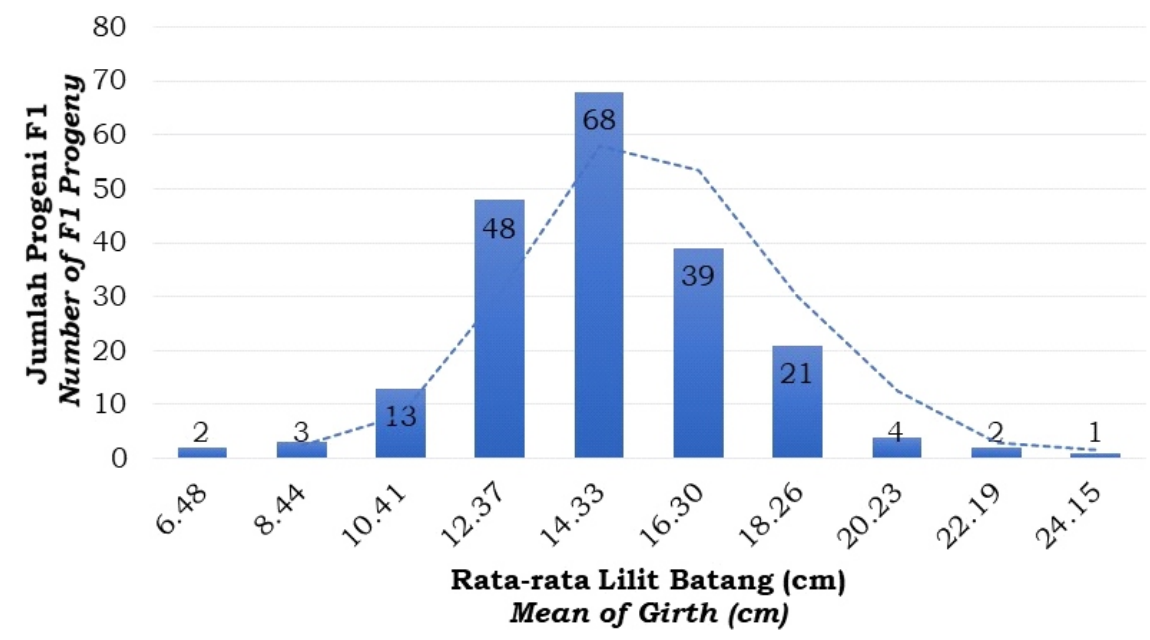

A

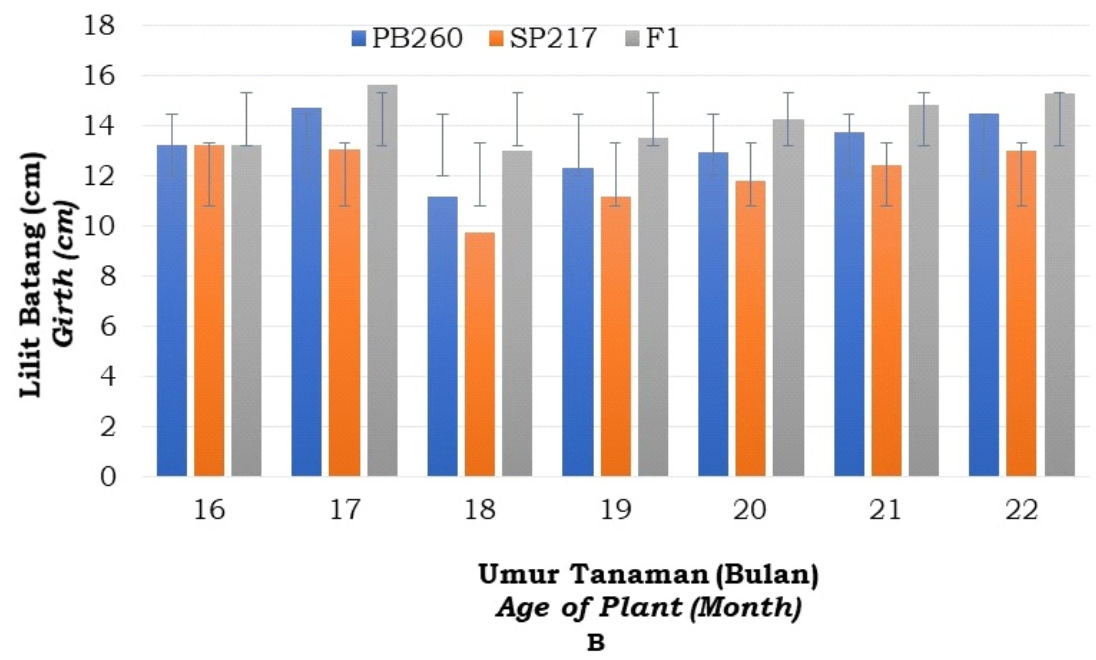

Gambar 1. Sebaran rata-rata lilit batang (A) dan perbandingan pertumbuhan lilit progeni F1 hasil persilangan PB 260 x SP 217 dengan kedua klon tetua pada umur $16-22$ bulan setelah tanam (B)

Figure 1. Distribution of girth $(A)$ and growth comparison of girth of $F 1$ progenies obtained from crossing of PB $260 \times S P 217$ with parent clone on 16-22 month after planting (B) 
Analisis phenotyping data pertumbuhan lilit batang dilakukan dengan menganalisis rata-rata lilit batang semua progeni F1 pada umur $16-22$ bulan (G16 G22) dan pertambahan lilit batang dari umur 16 sampai 22 bulan (Gi 16-22). Hasil analisis korelasi Pearson yang dilakukan dengan membandingkan perhitungan menggunakan aritmatika dan analisis BLUB (best linear unbiased prediction) menunjukkan tingginya korelasi pertumbuhan lilit batang antar bulan, namun untuk peningkatan pertumbuhan lilit batang masih tergolong moderat (Tabel 2). Informasi tersebut menunjukkan bahwa pengaruh faktor-faktor genetik dan lingkungan yang memengaruhi pertumbuhan lilit batang tanaman karet bersifat stabil setiap bulan selama masa pengamatan. Dengan demikian diperkirakan keberadaan QTL yang terpaut dengan pertumbuhan lilit batang tanaman karet adalah QTL mayor yang akan terdeteksi selama masa pengamatan tersebut (umur 16-22 bulan).

\section{Penyusunan Peta Pautan Genetik (genotyping) Populasi Hasil Persilangan PB 260 x SP 217}

Penyusunan peta pautan genetik atau linkage group (LG) 201 progeni $\mathrm{F} 1$ hasil persilangan klon PB 260 dengan SP 217 dilakukan menggunakan 263 marker SSR terseleksi. Hasil analisis keterpautan marka yang bersegregasi dengan pola 1:1:1:1, $1: 2: 1$, dan $1: 1$ menggunakan program Joint Map menghasilkan 22 kelompok pautan $(22$
LG) dengan jarak kelompok pautan berkisar 1 - 119,2 cm. Berdasarkan jumlah kromosom tanaman karet yaitu 18 kromosom, jumlah kelompok pautan yang diperoleh pada peta genetik ini sudah cukup baik. Hal ini karena kelompok pautan pada peta genetik merupakan representatif dari jumlah kromosom tanaman yang dianalisis (Collard et al., 2005). Pada tanaman karet, kelompok pautan ideal yang diharapkan adalah sebanyak 18 LG sesuai dengan jumlah kromosom.

Adanya perbedaan LG yang diperoleh pada penelitian dengan jumlah kromosom merupakan suatu hal yang dapat terjadi karena marka yang digunakan masih belum mampu mendeteksi beberapa bagian dari genom tanaman yang dianalisis. Hal tersebut dapat diatasi dengan penambahan marka-marka yang dapat menjembatani beberapa LG yang seharusnya berada dalam satu kesatuan. Penggunaan marka yang lebih banyak akan mampu menghasilkan peta pautan genetik dengan kerapatan yang tinggi (high density LG) (Collard et al., 2005; Collard \& Mackill, 2008).

Penyusunan peta pautan genetik pada penelitian dilakukan berdasarkan informasi penyusunan peta pautan genetik pada populasi hasil persilangan PB $260 \mathrm{x}$ RRIM 600 yang menggunakan marka SSR yang sama (Rattanawong et al., 2009). Berdasarkan informasi tersebut diketahui bahwa beberapa marker SSR yang berada pada LG berbeda pada analisis ini seharusnya berada dalam satu LG, sehingga

Tabel 2. Tabel korelasi lilit batang progeni F1 hasil persilangan PB 260 x SP 217 antar umur tanaman pada 16-22 bulan setelah tanam

Table 2. Correlation of girth of F1 progeny obtained from crossing of PB $260 \times$ SP 217 16-22 monthafter planting

\begin{tabular}{llllllll}
\hline $\begin{array}{l}\text { Variabel } \\
\text { Variable }\end{array}$ & G16 & G17 & G18 & G19 & G20 & G21 & G22 \\
\hline G17 & 0.94 & & & & & & \\
G18 & 0.92 & 0.95 & & & & & \\
G19 & 0.87 & 0.93 & 0.96 & & & & \\
G20 & 0.81 & 0.88 & 0.93 & 0.97 & & & \\
G21 & 0.79 & 0.85 & 0.90 & 0.95 & 0.97 & & \\
G22 & 0.76 & 0.82 & 0.88 & 0.93 & 0.96 & 0.98 & \\
Gi16-22 & 0.07 & 0.14 & 0.21 & 0.30 & 0.38 & 0.43 & 0.49 \\
\hline
\end{tabular}


dibutuhkan marka tambahan baik marka SSR, AFLP, STS, maupun SNP untuk menggabungkan marka-marka tersebut menjadi satu LG. Upaya penggabungan LG pada genome karet telah banyak dilaporkan. Lespinasse et al. (2000) memperoleh 18 kelompok pautan dengan kerapatan marka setiap $3 \mathrm{~cm}$ pada analisis 106 progeni $\mathrm{F} 1$ hasil persilangan PB $260 \times$ RO38 menggunakan 717 lokus yang terdiri dari 301 RFLP, 388 AFLP, 18 SSR, dan 10 isozim. Pada populasi yang sama, Le-Guen et al. (2007) menggunakan 234 marka SSR di mana marka tersebar setiap 10-15 cm. Demikian juga dengan analisis 351 progeni F1 hasil persilangan PB $260 \times$ MDF 180 menggunakan 203 marka SSR polimorfik, 96 AFLP, dan 1 STS yang menghasilkan 18 kelompok pautan (Le Guen et al., 2011a). Sedangkan Triwitayakorn et al. (2011) memperoleh 23 peta pautan dengan interval antar lokus sebesar $11,9 \mathrm{~cm}$ pada analisis 81 tanaman F1 dengan 97 lokus SSR.

Jumlah kelompok pautan dan kerapatan marka yang dihasilkan merupakan faktor penentu keberhasilan dalam proses identifikasi QTL. Semakin mendekati jumlah kromosom tanaman yang dianalisis dan semakin tinggi kerapatan marka dengan jarak yang dekat, maka akan semakin informatif peta pautan yang diperoleh. Hal ini menunjukkan bahwa semakin besar bagian genom yang dapat dianalisis. Beberapa peneliti melaporkan bahwa QTL yang terpaut dengan pertumbuhan lilit batang tanaman karet berhasil diidentifikasi pada 23 LG dengan kerapatan marka setiap $10 \mathrm{~cm}$ (Souza et al., 2013), 21 LG kerapatan $5 \mathrm{~cm}$ (Rosa et al., 2018), 18 LG kerapatan 3,5 cm (Conson et al., 2018), dan 15 LG dengan kerapatan marka $3 \mathrm{~cm}$ (An et al., 2019).

\section{Identifikasi QTL}

Berdasarkan analisis korelasi yang menunjukkan bahwa terdapat korelasi yang tinggi pertumbuhan lilit batang tanaman karet dari umur 16 sampai 22 bulan, maka analisis QTL dilakukan pada tanaman umur 22 bulan dengan perkiraan bahwa QTL tersebut dapat teridentifikasi pada semua umur tanaman. Selain itu, untuk memastikannya juga dilakukan analisis QTL pada pertambahan lilit batang dari umur 16 bulan ke 22 bulan.

Identifikasi keberadaan QTL yang terpaut dengan pertumbuhan lilit batang tanaman karet dilakukan dengan menggabungkan data peta pautan genetik yang diperoleh pada kegiatan genotyping dengan data pertumbuhan lilit batang hasil analisis phenotyping menggunakan software Map QTL. Hasil analisis menunjukkan bahwa terdapat tiga QTL yang terpaut dengan pertumbuhan lilit batang pada tanaman berumur 22 bulan setelah tanam yang berhasil diidentifikasi. QTL tersebut ditemukan pada LOD yang cukup tinggi yaitu 4,64 di LG no 14 dengan jarak 42,83 cM dari marka TAs2185, dan memberikan pengaruh sebesar $11,7 \%$ terhadap keragaman pertumbuhan lilit batang tanaman karet umur 22 bulan (Tabel 3). Menurut Collard et al. (2005) QTL yang memberikan pengaruh diatas $10 \%$ adalah tergolong QTL mayor, yang diperkirakan bersifat stabil dan tidak sensitif terhadap perubahan lingkungan. Berdasarkan informasi tersebut, diharapkan QTL yang berhasil diidentifikasi pada penelitian ini cukup kuat, stabil serta konsisten selalu ditemukan pada analisis pertumbuhan lilit batang selanjutnya.

Selain itu juga ditemukan putative QTL yang terpaut pertumbuhan lilit batang pada LOD 3,5 di LG 13 dan LOD 3 di LG 1 pada umur 22 bulan setelah tanam (Gambar 2). Hal ini berarti bahwa terdapat gen-gen atau sekuen DNA pada kromosom no 14, 13, dan 1 yang memengaruhi pertumbuhan lilit batang tanaman karet umur 22 bulan. Apabila dibandingkan dengan penelitian yang dilaporkan oleh Souza et al. (2013) terlihat bahwa LOD QTL terpaut pertumbuhan lilit batang yang teridentifikasi pada penelitian ini masih lebih rendah dimana pada penelitian tersebut diperoleh QTL pada LG 5 dengan LOD mencapai 5,41 , namun pengaruh QTL terhadap keragaman pertumbuhan lilit batang hanya 5,25\%. Rosa et al. (2018) melaporkan bahwa 15 QTL yang memberikan pengaruh sebesar $11,6 \%$ terhadap pertumbuhan berhasil diidentifikasi pada populasi hasil 
Oktavia

LG 14

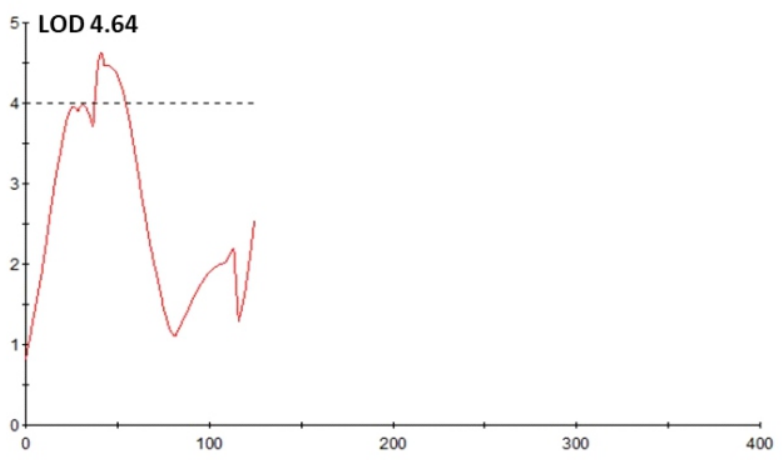

A

LG 1



LG 13



Gambar 2. Posisi QTL yang terpaut dengan pertumbuhan lilit batang populasi F1 hasil persilangan PB 260 x SP 217 umur 22 bulan setelah tanam pada linkage group 14 LOD 4,64 (A), linkage group 1 LOD 3 (B), dan linkage group 13 LOD 3,5 (C).

Figure 2. Position of QTLs linked to growth of girth of $F 1$ population obtained from crossing of PB 260 x SP 217 on 22 month old after planting on linkage group 14 LOD 4.64 (A), Linkage group 1 LOD 3 (B) and linkage group 13 LOD 3.5 (C). 
Tabel 3. Pengaruh QTL pada LG 14 terhadap variasi pertumbuhan lilit batang tanaman karet umur 22 bulan

Table 3. Effect of QTLs on LG 14 to variation of girth growth of rubber plant 22 month old

\begin{tabular}{|c|c|c|c|c|c|c|c|c|c|c|c|c|}
\hline Group & Position Locus & LOD & \# Iter. & mu_ac $\{00\}$ & mu_ad $\{00\}$ & mu_bc $\{00\}$ & mu_bd $\{00\}$ & Variance & $\%$ Expl. & GIC_1 & GIC_2 & GIC_m \\
\hline$g 14$ & 41.206 & 4.64 & 1 & 15.1476 & 15.8904 & 15.9831 & 16.2465 & 1.10186 & 11.7 & 0.950 & 0.954 & 0.952 \\
\hline$g 14$ & 40.206 & 4.59 & 1 & 15.1422 & 15.8816 & 15.9697 & 16.2549 & 1.10314 & 11.6 & 0.936 & 0.957 & 0.946 \\
\hline$g 14$ & 42.206 & 4.56 & 1 & 15.1751 & 15.8882 & 15.9915 & 16.2348 & 1.10410 & 11.5 & 0.977 & 0.975 & 0.976 \\
\hline$g 14$ & 43.828 & 4.47 & 1 & 15.1836 & 15.8829 & 15.9981 & 16.2347 & 1.10676 & 11.3 & 0.952 & 0.960 & 0.956 \\
\hline$g 14$ & 44.828 & 4.47 & 1 & 15.1672 & 15.8836 & 16.0013 & 16.2428 & 1.10671 & 11.3 & 0.907 & 0.923 & 0.915 \\
\hline$g 14$ & 45.828 & 4.47 & 1 & 15.1516 & 15.8845 & 16.0041 & 16.2504 & 1.10688 & 11.3 & 0.867 & 0.889 & 0.878 \\
\hline$g 14$ & $42.828 \mathrm{~g} 14 \mathrm{TAs} 2185$ & 4.46 & 1 & 15.2006 & 15.8822 & 15.9947 & 16.2262 & 1.10699 & 11.3 & 1.000 & 1.000 & 1.000 \\
\hline g14 & 46.828 & 4.45 & 1 & 15.1370 & 15.8856 & 16.0066 & 16.2573 & 1.10729 & 11.2 & 0.830 & 0.858 & 0.844 \\
\hline
\end{tabular}

persilangan PR 255 dan PB 217 dengan kerapatan marka mencapai $5 \mathrm{cM}$. Hasil terbaik dilaporkan oleh An et al. (2019), dimana dengan kerapatan marka yang mencapai 3,5 cM berhasil diidentifikasi total 38 QTL yang memberikan pengaruh mencapai $14,07 \%$ terhadap pertumbuhan diameter batang tanaman karet.

Identifikasi keberadaan QTL juga dilakukan pada pertambahan lilit batang dari tanaman umur 16 bulan sampai umur 22 bulan. Analisis menunjukkan bahwa QTL pada kromosom 14 juga ditemukan pada nilai LOD 4,1. Hal ini menunjukkan bahwa keberadaan QTL tersebut diduga kuat akan ditemukan pada pertumbuhan lilit batang di umur tanaman berikutnya (Gambar 3). Kestabilan keberadaan QTL tersebut akan diamati pada tahap pertumbuhan selanjutnya.

LG 14

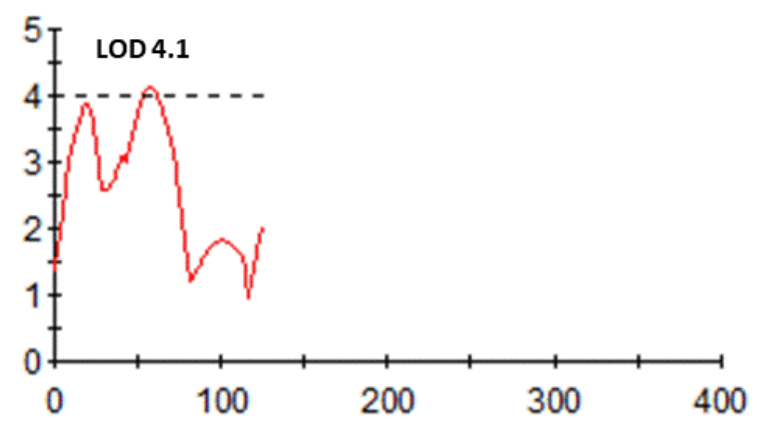

Gambar 3. Posisi QTL yang terpaut dengan penambahan lilit batang tanaman karet dari umur 16 sampai 22 bulan setelah tanam pada linkage group 14 LOD 4,1

Figure 3. Position of QTL linked to increasing of girth of rubber plant from 16-22 month old after planting on linkage group 14 LOD 4.1

\section{KESIMPULAN DAN SARAN}

Lilit batang progeni F1 hasil persilangan PB 260 x SP 217 umur 22 bulan setelah tanam berkisar 5,5 - 25,04 cm dengan rata-rata $14,66 \mathrm{~cm}$. Penambahan rata-rata lilit batang progeni $\mathrm{F} 1$ setiap bulan yaitu berkisar 0,4-1 cm. Berdasarkan koefisien keragaman terlihat bahwa terdapat keragaman segregasi pertumbuhan lilit batang yang cukup tinggi pada progeni F1. Analisis QTL menunjukkan bahwa terdapat tiga QTL yang terpaut dengan pertumbuhan lilit batang tanaman umur 22 bulan yang berhasil diidentifikasi yaitu pada LG no 14 pada LOD 4,64, LG no 13 LOD 3,5 dan LG 1 LOD 3. Selain itu juga ditemukan QTL yang terpaut dengan penambahan lilit batang tanaman umur 16 bulan sampai 22 bulan yaitu pada LG 14 LOD 4,1. Untuk melihat kestabilan keberadaan QTL tersebut perlu dianalisis secara berkala sesuai dengan pertumbuhan tanaman. 


\section{UCAPAN TERIMA KASIH}

Terima kasih diucapkan kepada Dr. Pascal Montoro dan Dr. Andre ClementDemange, Cirad, Perancis atas training, diskusi dan masukan yang diberikan selama penelitian pendahuluan dilakukan.

\section{DAFTAR PUSTAKA}

An, Z., Zhao, Y., Zhang, X., Huang, X., Hua, Y., Cheng, H., Li, X., \& Huang, H. (2019). A high-density genetic map and QTL mapping on growth and latex yield-related traits in Hevea brasiliensis Müll. Arg. Industrial Crops Production, 32, 440-448. doi: doi.org/10.1016/j.indcrop.2019.03.0 02 .

Chanroj, V., Rattanawong, R., Phumichai, T., Tangphatsornruang, S., \& Ukoskit, K. (2017). Genome-wide association mapping of latex yield and girth in Amazonianaccessions of Hevea brasiliensis grown in a suboptimal climate zone. Genomics, 109, 475-484. doi: http://dx.doi.org/ 10.1016/ j.ygeno.2017.07.005

Collard, B. C. Y., \& Mackill, D. J. (2008). Marker-assisted selection: an approach for precision plant breeding in twenty-first century. Philosophical Thansactions of the Royal Society, 363, 557-572.

Collard, B. C. Y., Jahufer, M. Z. Z., Brouwer, J. B., \& Pang, E. C. K. (2005). An introduction to markers, quantitative trait loci (QTL) mapping and markerassisted selection for crop improvement: The basic concepts. Euphytica, 142, 169-196.
Conson, A. R. O., Taniguti, C. H., Amadeu, R. R., Andreotti, I. A. A., de Souza, L. M., dos Santos, L. H. B., Rosa, J. R. B. F., Mantello, C. C., da Silva, C. C., José, S. J. E., Ribeiro, R. V., Le Guen, V., Garcia, A. A. F., de Souza, G. P., \& de Souza, A. P. (2018). High-resolution genetic map and QTL analysis of growth-related traits of Hevea brasiliensis cultivated under suboptimal temperature and humidity conditions. Front Plant Science, 9, 1255. doi: 10.3389/fpls.2018.01255

Grattapaglia, D., \& Sederoff, R. (1994). Genetic linkage maps of Eucaliptus grandis and Eucaliptus urophylla using pseudo-test-cross-mapping strategy and RAPD markers. Genetics, 137, 1121-1137.

Jansen, R. C. (1993). Interval mapping of multiple quantitative trait loci. Genetics, 135, 205-211.

Khan, S. (2015). QTL mapping: A tool for improvement in crop plants. Research Journal of Recent Sciences, 4, 7-12.

Lander, E. S., \& Botstein D. (1989). Mapping mendelian faktors underlying quantitative traits using RFLP linkage maps. Genetics, 121, 185- 199.

Le Guen, V., Garcia, D., Doaré, F., Mattos, C., Condina, V., Couturier, C., \& Seguin, M. (2011a). A rubber tree's durable resistance to Microcyclus ulei is conferred by a qualitative gene and a major quantitative resistance faktor. Tree Genetic Genome, 7, 877-889.

Le Guen, V., Garcia, D., Mattos, C., Doare, F., Lespinasse, D., \& Seguin, M. (2007). By passing of a phyllogenic Microcyclus ulei resistance in rubber tree analyzed by QTL detection. New Phytologist, $173,335-345$. 
Le Guen, V., Garcia, D., Mattos, C., Fouet, O., Doaré, F., Condina, V., \& Seguin, M. (2013). A newly identified locus controls complete resistance to Microcyclus ulei in the Fx2784 rubber clone. Tree Genetic Genome, 9(3), 805812. doi: 10.1007/s11295-013-05997.

Le Guen, V., Gay, C., Xiong, T. C., Souza, L. M., Rodier-Goud, M., \& Seguin M. ( $2011 \mathrm{~b})$. Development and characterization of 296 new polymorphic microsatellite markers for rubber tree (Hevea brasiliensis). Plant Breeding, 130(2), 294-296. doi: 10.1111/j.1439-0523.2010.01774.x

Le Guen, V., Lespinasse, D., Oliver, G., Rodier-Goud, M., Pinard, F., \& Seguin, M. (2003). Molecular mapping of genes conferring field resistance to South American Leaf Blight (Microcyclus ulei) in rubber tree. Theoritical and Applied Genetics, 108(1), 160-167. doi: $10.1007 / \mathrm{s} 00122-003-1407-9$

Lespinasse, D., Rodier-Goud, M., Grivet, L., Leconte, A., Legnate, H., \& Seguin, M. (2000). A saturated genetic linkage map of rubber tree (Hevea spp.) based on RFLP, AFLP, microsatellite and isozyme markers. Theoritical and Applied Genetics, 100, 127-138.

Novalina, \& Sagala, A. D. (2013). Construction of Hevea brasiliensis genetic linkage map and Identification of quantitative trait loci using RAPD markers. International Journal of Advance and Science Engineering Information Technology, 3(1), 71-75.

Oktavia, F., Sudarsono, Dinarti, D. (2021). Preliminary QTL detection for Corynespora leaf fall disease resistance in rubber plant. Nusantara Bioscience, 13, 53-61. doi: https://doi.org/10.13057/nusbiosci/ n130108
Ooijen, V. J. W. (2004). MapQTL® 5, Software for the mapping of quantitative trait loci in experimental populations. Wageningen, the Netherlands: Kyazma BV.

Orozco-Castillo, Chalmers, C., Waugh, R., \& Powell, W. (1994). Detection of genetic diversity and selective gen introgression in coffee using RAPD markers. Theoritical and Applied Genetics, 87, 934-940.

Rattanawong, R., Prapan, K., Lekawipat, N., Seguin, M., Clement-Demange, A. (2009). Detection of QTLs assotiation with growth, latex production and rubber quality for the development of Marker Asissted Selection (Hevea brasiliensis). IRRDB workshop on genome and transcriptome.

Rosa, J. R. B. F., Mantello, C. C., \& Garcia, D. (2018). QTL detection for growth and latex production in a full-sib rubber tree population cultivated under suboptimal climate conditions. $B M C$ Plant Biology, 18(223),1-16. doi: doi.org/10.1186/s 12870-018-1450-y.

Semagn, K., Bjornstad, A., \& Ndjiondjop, M. N. (2006). Principles, requirements and prospects of genetic mapping in plants. African Journal of Biotechnology, 5(25), 2569-2587.

Souza, L., Gazaffi, R., Mantello, C., Silva, C., Garcia, D., \& Le Guen, V. (2013). QTL mapping of growth-related traits in a full-sib family of rubber tree (Hevea brasiliensis) evaluated in a subtropical climate. PLoS One, 8(4), 1-10

Souza, L., Mantello, C., Suzuki, F., Rodrigo, G., \& Le Guen, V. (2011). Development of a genetic linkage map of rubber (Hevea brasiliensis) based on microsatellite markers. Paper presented at the IUFRO tree biotechnology conference. 26 Jun - 2 Jul 2011, Arraial D'Ajuda, Bahia, Brazil. 
Tran, D. M., Cle'ment-Demange, A., De’on, M., Garcia, D., Le Guen, V., Cle'mentVidal, A., et al. (2016). Genetic Determinism of sensitivity to Corynespora cassiicola exudates in rubber tree (Hevea brasiliensis). PLoS ONE, 11(10). doi:10.1371/journal. pone.0162807
Triwitayakorn, K., Chatkulkawin, P., Kanjanawattanawong, S., Sraphet, S., Yoocha, T., Sangsrakru, D. Chanprasert, J., Ngamphiw, C., Jomchai, N., Therawattanasuk, K., et al. (2011). Transcriptome sequencing of Hevea brasiliensis for development of microsatellite markers and construction of a genetic linkage map. DNA Research, 18, 471-482. 